\title{
The Ethiopian eunuch in transit: A migrant theoretical perspective
}

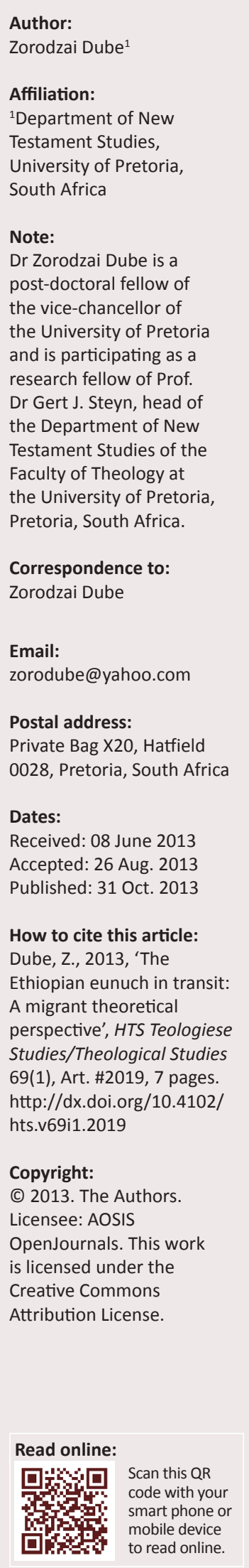

Biblical scholars tend to see the Ethiopian eunuch and court official through the eyes of Philip the evangelist, which is also what the author of the text wants us to do. However, the narrative about the Ethiopian court official is also a story about the experiences of an ancient traveller, and as such, the story invokes the tales of contemporary migrants. In this study, I explore how the story about a sojourning court official intersects with contemporary immigration and identity issues. My study demonstrates how the travelling court official can be used as a figure to think with and how his story mirrors challenges faced by migrant workers today.

\section{Introduction}

Because the interpretation of the Bible is a culturally embedded activity, the engagement with biblical hermeneutics is no innocent task. In Africa, the meaning of the biblical text has often been a tug of war between Western scholars' cultural presuppositions and the needs of African readers who see the academy reifying and distancing the meaning of the Bible from their daily life experiences. In the Western academic tradition, the Ethiopian eunuch story (Ac 8:26-40) has functioned as a missionary story about the disciple Philip who taught and evangelised the first African convert (Kartzow \& Moxnes 2010:184-204). Scott Shauf (2009:762-775) and Niels A. Dahl (1974:54-64) both argue, for example, that the story is about the expansion of Christianity to Gentile territories. Hence, in this tradition the eunuch story has served to justify the missionary enterprise and grant permission to convert Africans to the Christian religion. The question that Philip poses to the Ethiopian: 'Do you understand what you are reading?' only reinforced the Western presupposition that they were dealing with illiterate, uncouth and unenlightened people who were in need of their mission and cultural salvation. In modern postcolonial discourses the level of understanding has always been intertwined with power discourses, such that cultures with less literacy and lower scientific cognitive levels were regarded as less enlightened ( $p^{\prime}$ Bitek 1970:140). In spite of hermeneutical reflections, which were concerned either with the reconstruction of the historical world behind the text or the analysis of the narrative world within the text, the ultimate meaning was found in the world in front of the text - that is, in the missionaries' world. However, as my study will demonstrate, today's immigrant workers may also use the travelling Ethiopian as a figure to think with and his ancient story as a mirror that reflects the challenges they face. So I, too, read in front of the text, but in contrast with most biblical scholarship, I admit it. I thus situate myself amongst poststructuralist exegetes who argue that meaning is generated in the interface between reader and narrative and ultimately resides outside the text, in the reader's context and experiences. By arguing for this contextual meaning of the biblical stories, my study also disputes the existence of an ultimate and objective meaning of the text.

Migration is not an issue of the majority world alone, it certainly also concerns the Western world - in this case, the Scandinavian countries. Recently, the impact of wars in Afghanistan, Iraq and Somalia has become evident, even in Scandinavia, through the influx of immigrants from the affected countries. In addition, Norway has a high number of labour driven immigrants from Germany, Poland, Sweden, Denmark, the United Kingdom and several Asian countries. Several factors make Norway an attractive destination:

- the booming natural resource driven economy

- the concomitant large demand of labour

- the attendant boom in housing construction.

For six consecutive years, the United Nations has announced Norway to be the best place in the world to live - with the other Scandinavian countries closely behind in the contest. ${ }^{1}$ The global economic recession and instability and the associated political insecurity have exacerbated the number of people on the move. Residents from countries with weak economies in Eastern and Southern Europe - especially Spain, Portugal, Italy and Greece - now migrate to more affluent places for better opportunities. These European migrants are accompanied by people from West 
African countries such as Senegal, Gabon and Tunisia who - due to political and economic problems - brave to cross the Mediterranean Sea using makeshift boats to reach the gates of Europe: Spain, Portugal, Italy and Greece, again. The aftermath of the so-called Arab Spring has added extra volume to the people who decide to go west or north.

Besides being an economic question, immigration challenges national and cultural identity. The 2011 bombing in Oslo by Anders Breivik and his subsequent shooting of 77 youths at Utøya remind us of the complexity of this topic and its demand for equally complex answers. At the core of the immigration problem, the question remains: how do we treat people who come from other countries, who differ from us in terms of ethnicity, religion and culture - to mention some of the most important identity markers.

In this article, I will read Luke's story about the Ethiopian eunuch and court official (Ac 8:26-39) from the perspective of immigrants - that is, in the light of their experiences as well as in the light of the scholarly knowledge about migrants and their strategies of survival. My study contributes to biblical scholarship in the following manners:

- I demonstrate that the meaning of biblical stories is dependent on the context of the readers or hearers

- using migration theory, I re-describe the receptive meaning of the story

- I equip exegetes with new theories that may help them to move from a text-centred approach to a context-centred approach

- I reflect on social issues affecting our society, in this case immigration

- and I invite biblical interpreters to take this perspective as their starting point when they engage with the New Testament narratives.

\section{Luke's salvation history glosses over social tension (Ac 8:26-40)}

Luke, a theologian and historian, presented what he believed was a chronological salvation history of God to his own people during the late 1st century (c. $80 \mathrm{CE}$ ). Living at a time when the parousia had become a worrying expectation, Luke managed, in response, to shift the community's focus away from eagerly expecting the parousia, by introducing the ethical moral purpose of the church as an evangelising, mission oriented organ, aided by the active presence of the Holy Spirit (Bovon 2005:17). In doing this, Luke may be accused of sacrificing the eschatological motif, substituting it with salvation history, which he developed as far as back as the Old Testament and extended until the conclusion of Paul's ministry. In outlook, the salvation history focus contradicted the perception of the first Christians who eagerly awaited the immediate end of history. Francois Bovon (2005:17) suggests that Luke embarked on this project motivated by the sole reason that, if Christianity was to expand, it had to renounce the imminence of the parousia and assume the salvation history theme. Minimising the historical contradictions, Luke presented a salvation history that extended from the Old Testament to the time of Jesus and the disciples and then to Paul, whom many scholars accuse of misrepresenting Jesus and minimising the role and influence of the rest of Jesus' disciples in his ministry (see Gl 1:27).

The assimilation of Gentiles into the larger Judeo-Christian religion was one of the thorny issues that Luke had to deal with. According to Stephen G. Wilson (1973:29) the Jews had no ideology of evangelisation (reaching out to the Gentiles), since religion and national customs were inseparable. The gospels also seem to give evidence that there was disagreement with regard to the Gentile mission, for example, in the story of the Syrophoenician woman in Mark 7:24-30. Scholars are divided as to whether Jesus initiated a movement with a view to incorporate the Gentiles. For example, Adolf Harnack (1908:34) argues that all references to the Gentile mission did not originate with Jesus, but rather were later debates within the nascent church, whilst on the other hand Ferdinand Hahn (1965:131) thinks that from the onset Jesus accepted Gentiles and sinners, which caused him to clash with religious leaders of his time. Apparently, Luke overlooked these social conflicts within the early Christian movement and presented a 'salvation history scheme' of Christianity devoid of tension. One characteristic of Luke's historiography is the universalism of the gospel, which encompasses even Gentiles. This is evident as early as the birth of Jesus: Luke (2:30) clearly indicates that the birth of Jesus ushered in salvation to both the Israelites and the Gentiles. In addition, what Jesus and the disciples did was fulfilling God's plan.

Regarding this, the story of the Ethiopian eunuch carries similar motifs, in that Luke wants us to know that the meeting between Philip and the eunuch was a direct consequence of the Holy Spirit's intervention. The motif of the Holy Spirit and the fulfilment of prophecy are central themes in Luke's salvation history scheme; this is evident with the Holy Spirit guiding the disciples in their mission enterprise. In the eunuch story, the Holy Spirit led Philip into the desert to meet the eunuch (Ac 8:26). In Luke-Acts, the Holy Spirit is no longer an eschatological gift but a phenomenon that responds to the delay of the parousia (Wilson 1973:30). Because of the present active work of the Holy Spirit, the Gentile mission is no longer an eschatological event, but part of salvation history.

The exegesis of the passage (Ac 8:26-39) reveals that Luke concealed contentious issues regarding ethnicity, culture and social boundaries. This is 'evident from the opening of the story. The story begins by breaking social and geographical

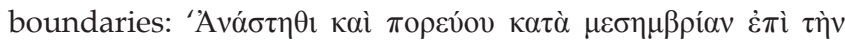

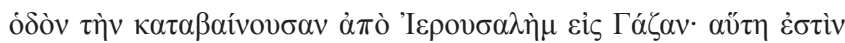

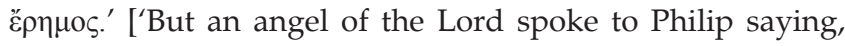
"Get up and go south to the road that descends from Jerusalem to Gaza" (This is a desert road)']. Moving from Jerusalem to Gaza (a desert place) presupposes transition from the known to the unknown, from the familiar to the unfamilar. But due to Luke's motif of the presence of the 
Holy Spirit and salvation history, embedded social issues that accompany such movement are muted in the text. I want to use migration theory to read against Luke's motifs. Migration theory will help unravel issues of identity and boundary conflict. Interestingly, having embarked on the sacred journey under the tutelage of the Spirit, Philip met an individual with a queer identity - the eunuch (Ev่voṽos). Again, Luke is mute regarding the prejudices and cultural presuppositions involved here. How would a 'full man' react upon meeting a eunuch and how does a eunuch react in view of a 'full man'? The eunuch is presented as a pilgrim going to Jerusalem to worship, which raises the question regarding his reception (v. 27). How do the insiders react to the encroachment of an outsider? Focusing on salvation history which glosses over conflict, Luke is oblivious to these thorny issues; instead, in verses 28 and 29 he seeks to show that the meeting was not coincidental, but rather part of fulfilling Old Testament prophecy (Isaiah), a motif central to salvation history. Philip's opening question 'A A $\alpha$ $\gamma \varepsilon$

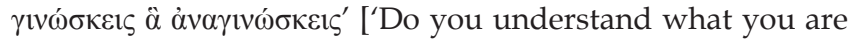
reading?'] is interesting from a postmodern perspective that treats knowledge and understanding as relative. From the story, Philip's question presupposes a contestation of other meanings, especially those of the eunuch, whilst at the same time favouring Luke's reading in view of salvation history, which stretches from the Old Testament, in this case Isaiah. Unfortunately, we are not told how the eunuch understood the story prior to Philip's arrival; instead, Luke is eager to reveal that the passage is from Isaiah and that it fulfils what happened to Jesus (vv. 32-34). Surely, the eunuch might not have heard about Jesus, but to respect his erroneous reading, Luke could have hinted at it, also for the sake of the readers. Using migration theory, I will problematise the discourse of power and social privilege, which silences social peripheral voices in favour of those that come from the centre. If the story muzzles discourses of power and social privilege, why is it that the eunuch seems to willingly invite Philip onto the chariot? To show that Philip knew the meaning of the passage better, Luke graphically details this through bodily

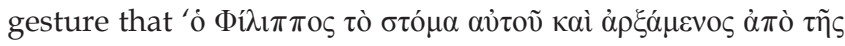
 opened his mouth, and beginning with this Scripture he told him the good news about Jesus'] - which portrays a posture of confidence and grasp of the salvation history (v. 35). To answer this, I use social exchange theory, which shows how people of different social status interact and how the socially underprivileged quickly surrender their viewpoints as a strategic move. The story concludes with the event of baptism (vv. 37-39), a central ritual during the 1st century that signified union and cohesion into one social group. I will further raise questions regarding social cohesion. Are outsiders easily accepted into the larger group without adjustments or conflict? I argue that Luke used salvation history to answer the question of the delay of the parousia and to explain the evangelisation of the Gentiles, but in doing so Luke glossed over thorny issues regarding social and ethnic differences. The humble contribution of this research is to attempt to imagine such tension, using migration theory.
I therefore read the story of the eunuch being mindful of Luke's salvation history framework and its subthemes of universalism, eschatology and the Holy Spirit, but instead reading it against the grain, with a view to unravel possible social and cultural tensions implicit in the eunuch story.

\section{Imagining the court officer's journey to Jerusalem}

I deliberately read the story against Luke's intention, by imagining the story as a narrative between the outsider (eunuch) and Philip who can be taken to represent a 'full' man, associated with the privileges of coming from Jerusalem. From the experiences of the many (including myself) for whom the search for a job has forced them to leave their home, the story about the Ethiopian eunuch echoes contemporary immigrants' challenges. Immigrants of all times are unfixed, vulnerable people, for whom being at home is the exceptional situation. They suffer both physical risks, which are due to the constant travelling and relocation, and psychological and social stigmatisation, because they are regarded as outsiders.

Travelling during ancient times was unsafe and frequently associated with perils - although this is not the obvious case with our eunuch and court official. In the story, the Ethiopian eunuch travelled by chariot, a means of transportation that reflected his social position as an attendant in queen Candace's court. Despite his somewhat better social position, as an ancient traveller the Ethiopian eunuch was still a vulnerable person subjective to several dangers (Shelton 1988:20). The risks included highwaymen and bad roadside food. Chariot travellers also suffered stress, because the roads were dusty and often in a bad condition. During sea voyages, travellers had very cramped quarters, and shipwreck and pirates threatened their journeys. Pliny the Younger (61-112 $\mathrm{CE})$, governor of the Roman province Pontus in present day Turkey, complained about the difficulties associated with travelling to his villas in the countryside for leisure. Pliny lamented the sandy roads, which slowed down the team pulling the carriage; it was faster to travel on horseback (Shelton 1988:20). Hence, the sandy roads might explain why Philip, who travelled by foot, was able to catch up with the Ethiopian eunuch's chariot. In addition to the possibility of ambush by robbers, the slow speed made chariot riders suffer longer days on trips, which would result in lack of proper food, fresh water, shelter and sleep (Shelton 1988:20).

Unlike the poor, rich people constantly travelled for business, leisure and diplomatic trips (Shelton 1988:22). They were either carried in litters borne by slaves or travelled in horse-driven chariots over bumpy roads (Shelton 1988:22). In general, the means for transportation signalled the traveller's social class: whilst the majority of the poor used donkeys, the rich rode horses. However, the most poor - amongst them the apostles - travelled by foot and carried their own goods.

The eunuch of our story travelled from Ethiopia to Jerusalem, which prompts our imagination of a foreigner in a foreign 
land. How was he received? How did he himself react to the challenges that faced him in this foreign culture? In the ancient world, the term Ethiopia signified a region beyond the borders, a place having mostly negative connotations. Kartzow and Moxnes (2010:184) think that being Black, Ethiopians were associated with demons, immoral behaviour and vices. We can imagine that his dark skin may have rendered the Ethiopian court official a conspicuous person. If he wanted to hide his identity and mingle anonymously with the inhabitants and pilgrims in Jerusalem, he would soon be recognised as a foreigner due to the colour of his skin - the indelible ink that marked him as an outsider.

However, the eunuch was no ordinary person (Kartzow \& Moxnes 2010:184). He was an official from the palace of the queen of Ethiopia - that is, he held a position endowed with many privileges. As servants in the royal courtyard, eunuchs were entrusted with the king's public messages. Some eunuchs served as royal treasurers whilst others were supervisors of the domestic chores - including the harem. Eunuchs were trusted persons because they were looked on as especially loyal to their superiors, due to the fact that they had no family or heirs themselves. Yet, the respect that was shown to eunuchs was confined to the courtyard; outside the court they were despised and ridiculed. Since the relatively privileged positions as treasurers or harem overseers were often the result of work promotion due to good and loyal work, it also revealed a servile, effeminate - and therefore despised - mentality. According to Scott Spencer (1992:155), the eunuchs remained under a cloud of suspicion despite the prosperity and fame that they acquired from servicing wealthy families. Even eunuchs who occupied high, social position suffered this stigmatisation and received negative labels. The Ethiopian's label 'eunuch' would therefore have had connotations of contempt and derision for first century listeners.

\section{The eunuch's experiences as mirror for immigrants}

Personally, the story about the Ethiopian eunuch in the Acts of the Apostles reminds me of the challenges immigrants face today. Although the stereotypes are old, they are deeply embedded in most contemporary cultures. Due to the sheer differences in skin colour, shape of the nose, face and hair, people traversing borders suffer xenophobic attacks and race motivated exclusions. In addition, today's immigrants also face the challenges of long-sometimes illegal-journeys, poor transport, food shortage and lack of shelter (Boswell 2005:4). Recently, we have seen how the people who fled the social unrest in Tunisia and Libya and crossed the Mediterranean in order to enter 'Fortress Europe' were received. At their arrival at Lampedusa in Italy, the immigrants were in need of tents, food, water and clothes. However, in response to the influx of immigrants from the African continent, citizens of the hosting countries reacted negatively with racism, anti-immigrant harassment and violence. Studies show that Europeans are anxious about: i) the 'ghettoization' of ethnic minorities in deprived cities

ii) the corresponding problem of interethnic tension and violence

iii) the poor educational and labour market performance of immigrants and ethnic minorities

iv) the criminality - and even terrorist activism - among ethnic groups

v) the perceived fragmentation of social solidarity and collective identities, which may be the result of increased cultural diversity. (Boswell 2005:5)

The declining ability of the European states to guarantee their citizens social and economic security - for example, in the form of stable employment and free access to various welfare institutions - has heightened this anxiety. Moreover, the destabilisation of traditional identity markers such as class, church, nation, profession, and family adds to the anxiety. However, the European public has shown a remarkable propensity to channel these anxieties into migration issues (Boswell 2005). In spite of the fact that immigrants face the same social challenges and often are affected in a more seriously way than the rest of the population, they are seen as part - or even as the cause - of the problem.

The low social position of eunuchs also reminds me of the low-paid jobs at the construction sites and in the textile and sewing industry (McGregor 2010:180). In general, immigrants get the most demeaning and low-paid jobs in the catering business (dishwashing) and the domestic zones (cleaning). In addition, immigrants are often not entitled to pensions and other work related benefits. Migration studies show that the immigration problem will continue in Europe as long as the companies want to boost their revenues through cheap labour.

In Norway, the majority of immigrants are employed in hotel housekeeping and newspaper distribution. A study carried out by JoAnn McGregor (2010:180) shows that despite their often-high qualifications, Zimbabwean immigrants in Britain are mostly employed in cleaning jobs. Even highly qualified people such as teachers, accountants, engineers, mechanics, administrators and bankers work as caregivers, for example, nursing old people. Most Zimbabwean immigrants find these kinds of employment deskilling and personally shameful, involving a loss of status (McGregor 2010:180). According to McGregor, the challenge of elderly care is the result of the combined fact that, on the one hand, British people live longer lives and, on the other hand, families get smaller. Yet, White women have proved unwilling to continue their traditional role as family caregivers. Instead, immigrants have been employed to clean, dress, bath and feed the elderly at care centres (McGregor 2010:180).

In most settings, local people find it awkward if a senior post is given to an immigrant (Delanty, Jones \& Wodak 2008:2). Recent studies show that unlike overt racism, there are clandestine strategies that exclude immigrants through repertoires such as 'protecting jobs', 'concern about welfare benefits', 'cultural incompatibilities' or lack of 'cultural 
competences', lack of will to integrate and lack of openminded, cultural 'tolerance' (Delanty et al. 2008:2). Like the eunuchs of antiquity, today's immigrants are viewed as outsiders and second-class citizens - if citizens at all. In order to avoid this stigmatisation, immigrants are ready to negotiate their identities. They strive to blend in with the home-born population. It is this desire to be seen as insiders that is the focus of the next section.

\section{Negotiating identities along the way}

Kartzow and Moxnes (2010:184) describe 'the road' as a place of transition where identities are ambiguous and fluid and where exchanges can take place. A text from the Old Testament prophet Isaiah plays an important role in revealing how, in his meeting with Philip, the eunuch negotiates his identity. The story introduces the eunuch as a person who does not understand the Scriptures. It is this lack of understanding that provides Philip with the opportunity to explain the good news about Jesus to him. Referring to the eunuch's lack of understanding, Robert F .O'Toole (1983:25) emphasises that Philip - in contrast to the eunuch - was under the guidance of the Spirit and therefore, by the latter's assistance, was able to interpret the Scriptures. It was also the Spirit which finally snatched Philip away (8:39). Due to the central role of the Spirit in the conversion of the eunuch, scholars, like Scott Shauf (2009:774), have claimed - in my view erroneously- that this story is about the expansion of the Christian gospel.

But as I read the story, it is primarily concerned with insider and outsider attitudes and therefore reminds me of immigrants' negotiation of their identities for the benefit of wellbeing - and maybe even survival. Personally, I experience Philip's attitude as condescending. Using the reference to the Spirit to legitimate and buffer his boldness, Philip proceeds as the (only) one who is enlightened. He has the right understanding of the Scriptures and he has the authority to decide whether there are any hindrances for the Ethiopian's baptism. This story influenced Western missionaries' attitudes towards non-Christians immensely, as it was used to validate their view of non-Christians as lacking in knowledge and as living in darkness (Dahl 1974:54).

As already stated, this is, in my view, a story about the outsider who wants to be regarded as insider. In the same way, today's immigrants yearn to be included into the cultures and identities of their host countries. We may wonder why the eunuch - seemingly so uncritically - accepted the epistemological premise of Philip's interpretation. Why did he not debate Philip's understanding of the text? I think that in this situation the eunuch acted like most immigrants who continuously yearn for acceptance and who are willing to barter their cultural heritage for the sake of peace and social acceptance.

To explore these dynamics, I will use social exchange theory, which sociology and social psychology use to explore how people negotiate their acceptance by surrendering some of their cultural beliefs and presuppositions (Molm 1997:12). Social exchange theory is a development of the mutual dependence theory in sociology, according to which people mutually exchange resources in order to strengthen their mutual dependency. Mutual dependence theory teaches that much of what we need in life - such as physical goods, psychological approvals, and social status - must be obtained from other people. The exchange of goods - broadly understood - forms patterns of dependency and enduring relations between people (Molm 1997:12). However, proponents of the social exchange theory dispute the way that society is conceptualised in the mutual dependence theory. They argue that social relationships are not always mutual and consensual; instead, more often than not relations are determined by power. Deviating from mutual dependence theory, social exchange theory claims that social exchanges produce hierarchical structures whereby the less dependent actors have advantages over those with fewer resources to invest in the negotiation of social relationships (Molm 1997:12).

One representative of the social exchange theory, Richard M. Emerson (1993:48), explains that due to mutual dependency, it is more or less imperative that each party is able to control or influence the other party's conduct by controlling the things that the other part values. Linda M. Molm (1997:14) laconically argues that, basically, social interaction is a mix of 'carrot' and 'stick'. The structure of power in a particular relationship determines the potential cost that each actor imposes on the other and this cost is equal to the other's dependence (Molm 1997:14). The social exchange theory has the following four assumptions:

i) The more dependent $B$ is on A for rewards, the higher the cost that A can impose on B by not providing these rewards.

ii) B's dependence on $A$ increases with the value of the outcomes that A can produce for B; it decreases with B's alternative sources of outcomes within the same domain.

iii) Actors initiate exchanges of benefit by giving rewards to other actors on whom they are dependent.

iv) Actors increase patterns of exchange that are relatively more rewarding or less costly, decrease those that are relatively less rewarding or more costly, and change behaviours when rewards decline or costs increase. (Molm 1997:17)

Social exchange theory defines coercion as the strategic use of power in order to increase the partner's reward by applying punishment or imposing cost on actors who fail to provide rewards in exchange. As Emerson (1993:49), rightly in my view, concludes: 'power resides implicitly in the other's dependency.' It is important to emphasise that the form of coercion to which I refer is not a forceful coercion; rather, it is the use of one's social advantages to make others act in a certain way. In response, actors evaluate the exchange outcomes and adopt actions that increase their social status, value and acceptance (Molm 1997:13). This means that in view of the options available, actors are likely to behave in a certain way in order to strengthen their possibility of survival. To cut the dependency circle, B must have alternative material resources outside the A-B relation (Emerson 1993:49). 
We can use this theory to understand the dynamics involved in the eunuch's negotiation of his identity in his encounter with the evangelist Philip. Three aspect of social exchange theory relate to the story. Firstly, given that the conversation took place on the road, which is a public place, the eunuch, who had an ambiguous social status, depended on Philip for public honour, acceptance and recognition. Hence, the balance of power was tilted in favour of Philip. Secondly, in the situation, Philip employed strategic coercion. He took advantage of his social position as apostle - and maybe also as fully male - to present his views. We may suppose that when the eunuch calculated his social benefits, he found it advantageous to listen to Philip. Philip acted strategically because as an evangelist he needed converts. In spite of his question to the eunuch: 'Do you understand what you are reading?' Philip was not interested in negotiating the meaning of the text. After all, the question was just a prelude to Philip's evangelisation, as the story indicates: 'then Philip opened his mouth and beginning with the Scripture he told him the good news of Jesus' (Ac 8:35). Philip had his end of the bargain: he got a convert for his religion. Thirdly, in response, the Ethiopian eunuch made a calculated decision. By strategically aligning himself with Philip, the eunuch undressed his peripheral identity and was baptised into that identity which was soon to be recognised as imperial religion. Therefore, using Emerson, we can suggest that the eunuch took a strategic move that enhanced his status.

The social exchange theory teaches us that people constantly make strategic choices that improve their chances of being happy, to live comfortable lives and to reduce risks in life. In my opinion, it is plausible to claim that the strategic choices that the eunuch made are comparable to how migrants today negotiate their identities in their various host countries. Lena Sawyer (2008:246), a Swedish cultural anthropologist, explains that migrants adopt strategic choices when faced with racism, threats and verbal abuse. She observes that instead of retaliating, migrants take a passive stance whereby they concentrate on 'matters of everyday life, family, love, grief, work-task problems, lifestyle, cultural pursuits, hobbies and enthusiasm' (Sawyer 2008:246). These strategies purposefully project the immigrants as better people than those who mistreat them. Migrants also calculate long-term benefits by adopting the stance that 'anyway you have to learn to live with it' (Sawyer 2008:246). These strategies help to control outward anger for the sake of survival. Migrants adopt these strategies in situations where retaliation in the form of expulsion and violence can be used against them. According to Sawyer (2008:246), immigrants train themselves to absorb insults without retaliating physically. They also socialise with each other to absorb insults and mistreatment as 'mechanism for teaching and sharpening the ability to control emotions and anger, an ability which was often necessary for survival.' Migrants are likely not to complain or press charges against locals out of fear of being victimised; instead, they present themselves as hardworking, pious and morally superior individuals. In this way, their behaviour situates them above those who discriminate against them. It is now the bully who is viewed as uncivil and on a low level of development (Sawyer 2008:246). Better moral standards provide the migrants with alternative definitions of worth and dignity as well as with an alternative discourse that seeks to undermine the anger and insults targeted at them.

\section{Contested happiness}

After Philip departed, the eunuch is reported to proceed on his journey rejoicing. In light of the above rereading of the story, which took migrants' experiences and strategies of survival into account, this twist in the story demands us to ask how a person who compromised so much for the sake of recognition can still be happy. With his theory of postcolonialism, the Indian-American scholar of literature, Homi K. Bhabha, may assist us to come up with an answer with which we can conclude this article.

According to Bhabha, the postcolonial situation is characterised by ambivalence with regard to distribution of power and dominance. Bhabha (1994:153) poignantly notes that ' $[t]$ he colonial presence is always ambivalent, split between its appearance as original and authoritative and its articulation as repetition and difference.'

The oppressive situation becomes ambivalent, because it does not always produce docile and obedient objects. This is because the oppressed often adopt ways of subverting the oppressor's project by mimicking it and by using subversive and hidden tactics. Mimicry is simultaneously resemblance and menace. It threatens and destabilises the status quo by mocking what the powerful regard as civility. For Bhabha (1994):

Mimicry emerges as the representation of a difference that is itself a disavowal. Mimicry is a double articulation, a complex strategy of reform, regulation, and discipline, which appropriates the other as it visualises power. (p. 86)

An analysis of various social negotiations reveals that due to constraints of power, people may tactically choose to do certain things for immediate benefit and long time survival.

When migrant and postcolonial studies are blended, the assumed happiness that concluded the Ethiopian eunuch's story appears as ambivalent or maybe even as a lip service that hides the real, social challenges. We may suspect that the Ethiopian eunuch and court official's expression of happiness was only his pretence of happiness - it was a mocking mimicry. On the surface, the happiness was meant to please Philip. Yet, deep down it was a mockery, since the eunuch only engaged in the discussions for strategic purposes and for personal benefit. Often social interactions are not transparent, but body language and other communication strategies may betray the discontent behind the presented happiness and satisfaction.

The situation may be recognisable to migrants who - for strategic purposes - do not express their genuine feelings 
nor react against mistreatment and injustice. Immigrants know that if they complain, they will be treated as ungrateful people. This accords with the observation of anthropologist James Scott (1990) that, when off-stage, oppressed people express their discontent in disguised forms of discourse such as spirit possession, gossip and rumours. Due to fear, immigrants camouflage their unpleasant experiences as happiness. Thus, migrants' public posturing is likely to deceive. As the discussion shows, negotiating identities whilst in foreign lands is not a pleasant exchange; instead, it is - as argued by the social exchange theorists - the 'survival of the fittest.'

\section{Conclusion}

Read from the perspective of migration studies, the eunuch story provides similar metaphors to those that we find in migrants. The story thus becomes a story of survival and a search for acceptance and relevance by a person who consciously understood his peripheral status. Again, using social exchange theory, we can conclude that the discussion between the eunuch and Philip unravels social identity issues, especially the desire by the eunuch to survive and to lessen inscribed negative perceptions about his identity. Using postcolonial theory, the story leaves us with an ambivalent relationship, one characterised by fear and suspicion. Like all immigrants, the eunuch needed to present a positive façade that concealed his real feelings.

\section{Acknowledgements Competing interests}

The author declares that he has no financial or personal relationship(s) which may have inappropriately influenced him in writing this article.

\section{References}

Bhabha, H.K., 1994, Location of culture, Routledge, London.

Boswell, C., 2005, 'Migration in Europe', paper prepared for the Policy Analysis and Research Programme of the Global Commission on International Migration, 06 September, viewed 22 May 2013, from http://storage.globalcitizen.net/data/ topic/knowledge/uploads/2010072785740705.pdf

Bovon, F., 2005, Luke the theologian: Fifty years of research (1950-2005), Baylor University Press, Waco.

Dahl, N.A., 1974, 'Nations in the New Testament', in E. Glasswell (ed.), New Testament Christianity for Africa and the world: Essays in honour of Harry Sawyer, pp. 54-64, SPCK, London.

Delanty, G., Jones, P.\& Wodak, R., 2008, 'Introduction: Migration, discrimination and belonging in Europe', in G. Delanty, P. Jones \& R. Wodak (eds.), Identity, belonging and migration, pp. 1-20, Liverpool University Press, Liverpool.

Emerson, R.M., 1993, 'Power-dependence relations', in Marvin E. Olsen \& Martin N. Marger (eds.), Power in modern societies, pp. 48-58, Westview Press, Oxford.

Hahn, F., 1965, Missions in the New Testament, SCM Press, London.

Harnack, A., 1908, The mission and expansion of Christianity, SCM Press, London.

Kartzow, M.B. \& Moxnes, H., 2010, 'Complex identities: Ethnicity, gender and religion in the story of the Ethiopian eunuch (Acts 8:26-40)', Religion and Theology 17(3/4), 184-204. http://dx.doi.org/10.1163/157430110X597827

McGregor, J., 2010, 'Between obligation, profit and shame: Zimbabwean migrants and the UK care industry', in Zimbabwe's exodus, crisis, migration, survival, pp. 179-206, SAMP, Cape Town.

Molm, L.M., 1997, Coercive power in social exchange, Cambridge University Press, Cambridge. http://dx.doi.org/10.1017/CBO9780511570919

O'Toole, R.F., 1983, 'Philip and the Ethiopian eunuch (Acts viii 25-40)', Journal for the Study of the New Testament 17, 25-34. http://dx.doi. org/10.1177/0142064X8300501705

p'Bitek, O., 1970, African religions in Western scholarship, East African Literature Bureau, Nairobi.

Sawyer, L., 2008, 'Voices of migrants: Solidarity and resistance', in G.Delanty, P. Jones $\&$ R. Wodak (eds), Identity, belonging and migration, pp. 241-260, Liverpool University Press, Liverpool.

Scott, J., 1990, Domination and arts of resistance: Hidden transcripts, Yale University Press, New Haven.

Shauf, S., 2009, 'Locating the Ethiopian eunuch: Characterisation and narrative context in Acts 8:26-40', Catholic Biblical Quarterly 71, 762-775.

Shelton, J., 1988, A sourcebook in Roman social history, Oxford University Press, Oxford.

Spencer, F.S., 1992, 'The Ethiopianeunuchand his Bible: Asocial-science analysis', Biblical Theology Bulletin 22, 155-165. http://dx.doi.org/10.1177/014610799202200403

United Nations, n.d., Immigration to Norway increasing, viewed 22 May 2013, from http://www.workpermit.com/news/2007-05-08/norway/record-immigrationstatistics-2006.htm

Wilson, S.G., 1973, The Gentiles and the Gentile mission in Luke-Acts, Cambridge University Press, Cambridge. http://dx.doi.org/10.1017/CBO9780511659669 